\title{
Jak učitelé využívají venkovní prostředí pro výuku vzdělávací oblasti Člověk a jeho svět
}

\author{
Štěpánka Chmelová
}

Jihočeská univerzita v Českých Budějovicích, Pedagogická fakulta, Katedra biologie

Redakci zasláno 14. 12. 2020 / upravená verze obdržena 17. 2. 2021 /

/ k uveřejnění přijato 17. 2. 2021

\begin{abstract}
Abstrakt: Hlavním cílem této studie bylo zjistit, jak je aktuálně využívána výuka ve venkovním prostředí učiteli 1 . stupně základních škol. Protože učitelé 1 . stupně většinou vyučují celou škálu předmětů, pozornost studie byla soustředěna jen na př́rodovědné předměty - prvouku a př́rodovědu. Na této studii participovalo celkem 120 učitelů vyučujících dané předměty na 1 . stupni základní školy napříč Českou republikou. Jako výzkumný nástroj byl zvolen nestandardizovaný autorský dotazník, který ćítal celkem 18 otázek. Studie probíhala v letech 2019 a 2020, a rekognoskuje tak aktuální stav výuky těchto předmětů ve venkovním prostředí. Bylo zjištěno, že 97 \% respondentů využívá pravidelně výuku ve venkovním prostředí. Studie byla navíc doplněna rozhovory s 20 učiteli z praxe, kterým bylo položeno pět otázek k tématu výuky ve venkovním prostředí.
\end{abstract}

Klíčová slova: Člověk a jeho svět, výuka ve venkovním prostředí, dotazníky

\section{Teoretická východiska}

Výuka ve venkovním prostředí v současné době nabývá celosvětově na popularitě (Mc Sweeney \& WinklerPrins, 2020). U nás je známá spíše pod pojmem terénní výuka, která má ale mnoho podob (Svobodová et al., 2019).

Oost a kol. (2011) definují terénní výuku jako „podnikání výukových aktivit ve venkovním prostředí" (in outdoor setting). Dle Hofmanna a kol. (2011) je terénní výuka „komplexní výuková forma zahrnující různé vyučovací metody, mezi něž patří např́klad pozorování, pokus, projektová metoda, kooperativní metody a metody zážitkové pedagogiky“. Z hlediska organizační formy výuky se v rámci terénního vzdělávání uplatňují především terénní cvičení, vycházky do přírody, exkurze, tematicky zaměřené výlety a expedice v terénu mimo školu (Činčera et al., 2019).

Dnes je převážně pedagogickými pracovníky využíván pojem „výuka venku“ neboli „výuka ve venkovním prostředí“, kterou zavedli čeští autoři (např Daniš, 
2018; vzdělávací centra Tereza, Chaloupky a Lipka). Proto i v této studii ji budeme nazývat především výukou ve venkovním prostředí. Ve světě je tato výuka známá pod pojmem „education outside the classroom“ (Bentsen et al., 2021; Waite, 2020).

Mnohé práce i u nás komplexně posuzují význam výuky ve venkovním prostředí (např. Daniš, 2016, 2018) či výuky venku v prostředí školních zahrad (Ryplová et al., 2019). Důvodem k její implementaci ve výuce je kromě edukačních cílů dnes zejména odcizování dětí od přírody a velmi malý podíl volného času, který děti tráví venku (Daniš, 2016; Jančaříková, 2010; Louv, 2008). Míra kontaktu s přírodou v dětství má rozhodující vliv na vztah člověka a prrírody v dospělosti (Asah et al., 2012).

Dle rozsáhlého výzkumu (1515 respondentů ve věku 7-15 let) Nadace proměny Karla Komárka (2016) bylo zjištěno, že čeští školáci tráví během výuky poměrně málo času venku: jen $1 \%$ jich bylo $\mathrm{v}$ dotazovaném týdnu během výuky na ulici, $5 \%$ v prŕrodě, $6 \%$ na zahradě, $7 \%$ v parku a $8 \%$ na hřišti. Dle Jančaříkové a Kapuciánové (2016) je výuka venku přitom pro děti zcela přirozená.

Výuka ve venkovním prostředí má mnoho prokazatelných výhod, ty uvádí souhrnně např. Wells (2000), Bento a Dias (2017) nebo Suttie (2018):

- Učení venku žáky baví, je pro ně přirozené.

- Učení venku je názorné.

- Při učení venku se zlepšuje pozornost a soustředění žáků a také kognitivní schopnosti.

- Pohyb venku pomáhá snižovat nadváhu, obezitu, má příznivý vliv na imunitní systém dětí.

- Učení venku pomáhá odbourávat stres, přispívá ke zlepšení duševního zdraví.

- Učení venku posiluje vztahy mezi dětmi, podílí se na snížení agresivity.

Berg a kol. (2020) potvrdili důležitost výuky ve venkovním prostředí pro lepší environmentální chápání a propojení s př́írodou. Jančaříková (2010) uvádí, že venkovní prostředí poskytuje žákům nenahraditelné možnosti drobných kontaktů a impulsů, které působí pozitivně na rozvoj osobnosti a environmentální senzitivity. Ve Velké Británii zaznamenali Marchant a kol. 
(2019) při zavedení pravidelné výuky ve venkovním prostředí zkoumaných škol velké př́nosy v zapojení žáků (9-11 let) do učení, zlepšilo se i jejich soustředění, chování, zdravotní stav a celková spokojenost jak žáků, tak i učitelů. Činčera a Holec (2016) představili rovněž poměrně rozsáhlou studii potenciálních pozitivních efektů terénní výuky na znalosti, postoje, dovednosti i chování žáků.

Výuka ve venkovním prostředí je spjata většinou s přírodovědným vzděláváním. Vzdělávací oblast Člověk a jeho svět je z hlediska učiva rozdělena do pěti tematických okruhů - Místo, kde žijeme, Lidé a čas, Lidé kolem nás, Rozmanitost př́rody a Člověk a jeho zdraví (RVP ZV, 2017). Jednotlivé okruhy se vzájemně prolínají a obsahově na sebe navazují v každém ročníku primárního stupně vzdělávání. Přehledně uvádí dosud používané koncepce vzdělávacího obsahu a př́rodovědného poznávání na 1. stupni základní školy u nás například Podroužek (2003) a Šimik a kol. (2010, 2015). V současné době dochází k úpravám RVP ZV od 1. 9. 2021, povinně pak od roku 2023 pro 1. stupeň ZŠ (MŠMT, 2021). Plánované úpravy RVP se dotknou celé řady přírodovědných předmětů včetně této vzdělávací oblasti (dojde k eliminaci některého učiva a k redukci časové dotace předmětů). S ohledem na probíhající změny bude nutná již dlouhodobě diskutovaná úprava koncepce přírodovědného vzdělávání (Hajerová Müllerová \& Slavík, 2020; Hejnová, 2011; Held, 2011) či směřování ke konstruktivistickému přístupu k učení, který umožňuje učení spíše na základě organizace myšlenek a získávání zkušeností (Veřmiřovský \& Oujezdský, 2014). Pro tento přístup k výuce přírodovědných předmětů se výuka ve venkovním prostředí přímo nabízí. Výuka ve venkovním prostředí kromě objevování a poznávání vytváří i pozitivní vztah žáků k přírodě, umožňuje integrovat vzdělávací obsahy, realizovat badatelské aktivity, aktivizovat žáky, a hlavně myšlenkové procesy žáků využitím škály aktivizačních vyučovacích metod (Brtnová Čepičková, 2013).

Primární přírodovědné vzdělávání dává základy pro výuku přírodovědných předmětů na 2. stupni základní školy. V České republice neexistuje žádný předpis, který by stanovil povinnou časovou dotaci výuky ve venkovním prostředí ani povinnost škol vlastnit školní zahradu či na ní venku vyučovat. Svobodová a kol. (2019) ve svém výzkumu zjistili, že na 1. stupni ZŠ byla terénní výuka zastoupena ve školních vzdělávacích programech (ŠVP) jen u 9 škol ze zkoumaných 50, a to ve vzdělávací oblasti Člověk a jeho svět. 
V současné epidemiologické situaci však Ministerstvo školství, mládeže a tělovýchovy (MŠMT, 2020) vydává metodický pokyn k distanční formě vzdělávání, kde naopak výuku venku doporučuje a podporuje ve všech předmětech. Podroužek (2003) uvádí, že v prvouce a př́rodovědě je žádoucí, aby žáci využívali co možná nejvíce živé přírodniny v přirozeném přírodním prostředí. Rovněž je nutná i znalost tzv. aplikované př́rodovědy, tj. takových přírodovědných znalostí, které žák může bezprostředně uplatňovat v praktickém životě (Podroužek, 2005). Pro zajištění těchto znalostí je výuka ve venkovním prostředí nenahraditelná.

RVP ZV samozřejmě neomezuje možnost vyučovat ve venkovním prostředí. $\mathrm{Na}$ 1. stupni se ale v těchto dokumentech dle Burešové a kol. $(2019$, s. 8) zdůrazňuje potřeba výuky venku, viz např. některé formulace $v$ charakteristice vzdělávací oblasti Člověk a jeho svět: „Důraz je kladen na praktické poznávání místních a regionálních skutečností a na utváření přímých zkušeností žáků.“; „Na základě praktického poznávání okolní krajiny a dalších informací se žáci učí hledat důkazy o proměnách př́rody, učí se využívat a hodnotit svá pozorování a záznamy, sledovat vliv lidské činnosti na př́rodu, hledat možnosti, jak ve svém věku přispět k ochraně přírody, zlepšení životního prostředí a k trvale udržitelnému rozvoji.“; „Potřebné vědomosti a dovednosti ve vzdělávacím oboru získávají žáci především tím, že pozorují názorné pomůcky, přírodu a činnosti lidí, hrají určené role, řeší modelové situace atd." Rovněž Šimik (2015) uvádí jako jednu z podmínek úspěšného vzdělávání vlastní prožitek žáků vycházející z konkrétních nebo modelových situací. Důležitým aspektem je také snaha o propojení této vzdělávací oblasti s reálným životem a s praktickou zkušeností žákủ. Výuka ve venkovním prostředí by tak měla být nedílnou součástí výuky př́rodovědných předmětů (Činčera \& Holec, 2016; Daniš, 2018).

Tato studie se proto snaží odpovědět na otázky: Je výuka ve venkovním prostředí uplatňována učiteli $\mathrm{v}$ př́rodovědných předmětech na 1 . stupni ZŠ? Jak je výuka prvouky a přírodovědy ve venkovním prostředí v českých školách realizována? 


\section{Metodologie výzkumu}

\subsection{Cíl výzkumu}

Hlavním cílem této studie bylo zjistit, jakým způsobem využívají výuku ve venkovním prostředí učitelé 1 . stupně základních škol. Protože učitelé 1. stupně většinou vyučují celou škálu předmětů, pozornost studie byla soustředěna jen na předměty prvouka a př́rodověda.

Účelem této studie bylo zjistit, jaké jsou reálné možnosti učitelů vyučovat ve venkovním prostředí, do jaké míry a jak často výuku ve venkovním prostředí uskutečňují. Byla položena hlavní výzkumná otázka: Je učiteli v přírodovědných předmětech na 1 . stupni základní školy uplatňována výuka ve venkovním prostředí? Dílčí dvě výzkumné otázky (Jaká jsou pozitiva výuky ve venkovním prostředí? Jaká jsou negativa výuky ve venkovním prostředí?) se týkaly shrnutí a uvedení konkrétních pozitiv a negativ této specifické výuky z pohledu učitelů. Tato studie je tedy určitým pilotním monitoringem situace výuky ve venkovním prostředí na českých školách. Dotazníkové šetření bylo doplněno ještě krátkými řízenými rozhovory s 20 učiteli. Předmětem rozhovorů bylo především upřesnění informací $\mathrm{k}$ výuce ve venkovním prostředí př́mo od pedagogů z praxe.

\subsection{Dotazníkové šetření}

Jako výzkumný nástroj byl zvolen nestandardizovaný polostrukturovaný dotazník (uvedený jako př́loha na konci textu). Vytvořený dotazník prošel na souboru 60 respondentů rozsáhlou pilotáží v roce 2018 a následně byl korigován. Dotazník obsahoval popisnou část - 4 otázky (pohlaví, délka pedagogické praxe, specifikace školy, kraj) - a dalších 18 otázek zaměřených na způsobu využívání venkovního prostředí pro výuku př́rodovědných předmětů (prvouky a př́rodovědy). Dotazník byl tvořen otázkami bud's volbou odpovědí (dichotomické, polytomické), nebo s možností volných odpovědí. Protože výuka venku často probíhá na školních zahradách (Ryplová et al., 2019), čtyři otázky v dotazníku se týkaly funkce školních zahrad - zda na dané škole respondent má zahradu k dispozici a zda ji k výuce využívá, ev. jaké další předměty zde vyučuje. Následující otázky (č. 6-18) se již zaměřily na samotnou výuku ve venkovním prostředí - např na konkrétní místo realizace této výuky, nejčastější hodinovou dotaci, spokojenost s materiálním vybavením školy pro výuku ve venkovním prostředí, preference 
vyučovaných témat $\mathrm{v}$ rámci prvouky a přírodovědy, nejčastější volené výukové metody a formy. Řada respondentů bohužel při pilotáži měla s těmito pojmy problém, proto byly některé otevřené otázky nakonec po pilotáži doplněny výběrem $\mathrm{z}$ odpovědí. $\mathrm{V}$ dalších otázkách pak respondenti odpovídali na otázky týkající se časové náročnosti a př́pravy této výuky, uváděli v otevřených otázkách pozitiva a negativa spojená s výukou venku. Poslední otázka se zabývala zjištěním, jaké výukové materiály k této výuce učitelé používají, kde hledají nejčastěji inspiraci.

Dotazníkové šetření probíhalo během let 2019 a 2020. Na kvantitativní části studie participovalo celkem 120 učitelů vyučujících dané předměty přímo na 1. stupni základní školy. Respondenti pocházeli z různých krajů České republiky a byli osloveni pro dotazníkové šetření při kurzech celoživotního vzdělávání na Jihočeské univerzitě v Českých Budějovicích. Od celkového počtu 180 oslovených učitelů se podařilo získat 120 plně vyplněných dotazníků, návratnost tedy činila 67 \%. Dotazníky byly vyhodnoceny s použitím programu MS Excel. K vyhodnocení dotazníků byla použita základní popisná statistika (četnost, procenta). Otevřené otázky byly kódovány a následně byly odpovědi kategorizovány s uvedením jejich četnosti (Hendl, 2016). U otázek s výběrem odpovědí byly vždy počítány četnosti volených odpovědí, u některých otázek byly přepočítány na procenta. Výsledky dotazníkového šetření otázek pak byly pro přehlednost zpracovány do grafů, z nichž nejdůležitější jsou uvedeny v kapitole 3.

Průměrná délka pedagogické praxe skupiny respondentů činila 6,5 roku. Minimální délka pedagogické praxe byla 1 rok, maximální zjištěná délka učitelské praxe pak byla 18 let. Průměrná délka pedagogické praxe je v souhrnu poměrně nízká pravděpodobně $\mathrm{z}$ důvodu dalšího doplňkového studia, které nejčastěji respondenti absolvují co nejdřive po dokončení vysokoškolského studia (viz předchozí kapitola). Z hlediska pohlaví se jednalo výlučně o ženy. Respondenti (v práci budeme nazývat takto neutrálně) pocházeli z těchto krajů České republiky: Jihočeský, Jihomoravský, Středočeský a Pardubický kraj, dále Plzeňský kraj a kraj Vysočina. Až $42 \%$ respondentů vyučuje převážně na malých vesnických školách, 17 \% pak vyučuje na málotřídní škole, $17 \%$ rovněž na školách ve městech pod 50 tisíc obyvatel, $17 \%$ ve městech do 100 tisíc obyvatel a 7 \% na školách v městech nad 100 tisíc obyvatel. 


\section{3 Řízené rozhovory}

Kvantitativní studie byla navíc rozšířena o doplňkový kvalitativní výzkum na vybraném souboru respondentů. Tento doplňkový kvalitativní výzkum vznikl ze situace při pilotáži, kdy mnozí respondenti rádi hovořili o výuce ve venkovním prostředí, a doplňovali tak dotazníky ústním komentářem. $\mathrm{Na}$ základě této zkušenosti byl připojen ještě tento kvalitativní výzkum. Jednalo se o krátký řízený rozhovor s celkem 20 respondenty. Rozhovor se zaměřil na možné konkrétní postřehy, pozitiva výuky ve venkovním prostředí či problémy, které se s ní pojí, dále na vnímání postojů a přístupu žáků a rodičů $\mathrm{k}$ této výuce. $\mathrm{V}$ rámci řízeného rozhovoru bylo položeno celkem pět otázek. Uvedené rozhovory pak byly přepsány. Ke zpracování těchto kvalitativních dat byla použita metoda otevřeného kódování a následná kategorizace dat (Hendl, 2016; Punch, 2008).

Výzkumné šetření probíhalo rovněž během let 2019 a 2020. Průměrná učitelská praxe těchto respondentů činila 9 let. $V$ řízeném rozhovoru byly položeny následující otázky:

- Jak vnímáte přístup žáků k výuce ve venkovním prostředí?

- Jaký vnímáte postoj rodičů k výuce ve venkovním prostředí?

- Máte nějaké zajímavé postřehy z výuky ve venkovním prostředí?

- Stala se Vám nějaká nepř́ijemnost během výuky ve venkovním prostředí (např. úraz)?

- Jaké má podle Vás výuka ve venkovním prostředí limity a nevýhody?

\section{Výsledky a diskuze}

\subsection{Vyhodnocení dotazníkového šetření}

Prioritou této studie bylo zjištění využití venkovního prostředí pro výuku prvouky a př́rodovědy na 1 . stupni základních škol. Kapitola uvádí a diskutuje výsledky z položených 18 otázek dotazníku.

Z výsledků této dotazníkové studie vyplývá, že většina vyučujících (97 \%) pravidelně využívá výuku ve venkovním prostředí.

Další otázky v dotazníku se týkaly využívání školní zahrady k výuce prvouky a př́rodovědy, pokud školní zahradu samozřejmě na dané škole mají 
k dispozici. Dle zjištění 58 \% respondentů realizuje výuku prvouky a př́rodovědy právě v tomto modelovém prostředí (nemělo by se však jednat čistě o zahradnické práce - praktické činnosti). Ostatní respondenti uváděli absenci školní zahrady jako důvod, proč v tomto prostředí výuka neprobíhá. Další otázka se týkala začlenění výuky v prostředí školních zahrad do výuky prvouky a přírodovědy. Většina respondentů vyučuje na školních zahradách právě prvouku a př́rodovědu (58 \%). Jako druhý nejčastěji vyučovaný předmět v prostředí školní zahrady uváděli respondenti pracovní činnosti (uvedlo 37,5 \% respondentů). Respondenti uvedli také tělesnou výchovu, matematiku, český jazyk a výtvarnou výchovou. Podobné výsledky uvádí i Vácha (2015) ve svém výzkumu zaměřeném na využití školních zahrad na primárním stupni základních škol. Školní zahrady a jejich vybavení mají při výuce ve venkovním prostředí důležitou roli. Školní zahrady propojují teoretické a praktické dovednosti žáků, jsou místem pro zážitkové učení a splňují požadavky pro venkovní výuku z hlediska dostupnosti a materiálního zabezpečení (Ryplová et al., 2019; Williams \& Brown, 2012). Blair (2009) uvádí ve své studii zlepšení přírodovědných znalostí žáků při výuce v prostředí školních zahrad a rovněž zlepšení sociálního a environmentálního chování žáků. Zde hraje samozřejmě roli otázka, jak často se výuka ve venkovním prostředí ve školách uskutečňuje.

Respondenti nejčastěji uváděli, že ve venkovním prostředí vyučují jednou měsíčně (42\%), jednou týdně pak 33 \% dotazovaných pedagogů. Další intervaly byly pak uvedené jednou za tři měsíce (17 \%) a jednou za šest měsíců (8\%).

Z výčtu míst, kde respondenti výuku ve venkovním prostředí přímo realizují nejčastěji, bylo respondenty uváděno blízké okolí školy (pole, louky, lesy). Toto prostředí využívá $80 \%$ z dotazovaných učitelů. Nejbližší okolí školy nebo obce samozřejmě patří všeobecně mezi nejvíce exponované prostředí pro výuku ve venkovním prostředí. Výuku realizovanou v prostředí školních zahrad uvedlo 58 \% respondentů. Mezi další místa pak patřily např. trávník hned u budovy školy bez aspektu školní zahrady (23 \%) či městské parky (11\%). Hofmann (2003) rozděluje výuku z hlediska krajiny, ve které výuka probíhá např. na krajinu přírodní více či méně pozměněnou, krajinu kulturní více či méně pozměněnou, silně pozměněnou, městskou a venkovskou. Adekvátně vybavené školní zahrady pak umožňují nahrazovat toto prostředí, a výuka venku v prostředí školních zahrad tak mủže být dostupnější (Chmelová, 2010; Chmelová et al., 2019). 
Časová dotace výuky ve venkovním prostředí, kterou respondenti nejčastěji uvedli, se pohybuje od dvou vyučovacích hodin (67\% respondentů) k jedné vyučovací hodině (50 \%) trávené výukou venku týdně. Většina dotazovaných učitelů tedy nejraději spojuje dvě vyučovací jednotky. Jen $12 \%$ respondentů pak uvedlo, že blok výuky venku zařazují na celý den. Na 1. stupni ZŠ je vhodné výukové jednotky spojovat, a věnovat se tak výuce ve venkovním prostředí déle než jen 45 minut. Šetří se tím čas, který zaberou např. přechody/doprava na venkovní stanoviště. Svobodová a kol. (2019) ve svém výzkumu na 50 základních školách identifikovali rovněž nejčastěji krátkodobou terénní výuku (1-2 vyučovací jednotky).

Příprava (souhrnně teoretická a materiální) na vyučovací lekci ve venkovním prostředí zabere učitelům nejčastěji 60 minut (42\% dotazovaných), více než 2 hodiny (25 \%), některým 30 minut (19\%), ostatním pak 3 hodiny a více (14\%). S materiálním vybavením školy pro venkovní výuku je většina vyučujících spokojena (uvedlo $95 \%$ respondentů).

Nejvíce pedagogové vyučují venku tato čtyři témata z prvouky: rostliny, roční období v přírodě, počasí a živočichové. Obrázek 1 zobrazuje uvedené četnosti odpovědí pro jednotlivá témata. $Z$ těchto výsledků je patrné, že se výuka $\mathrm{v}$ prvních třech ročnících základní školy zaměřuje $\mathrm{v}$ rámci přírodovědných předmětů na učivo živé přírody a vnímání změn $\mathrm{v}$ přírodě během kalendářního roku.

\section{Obrázek 1}

Vyučovaná témata $\mathrm{z}$ prvouky $(n=120)$

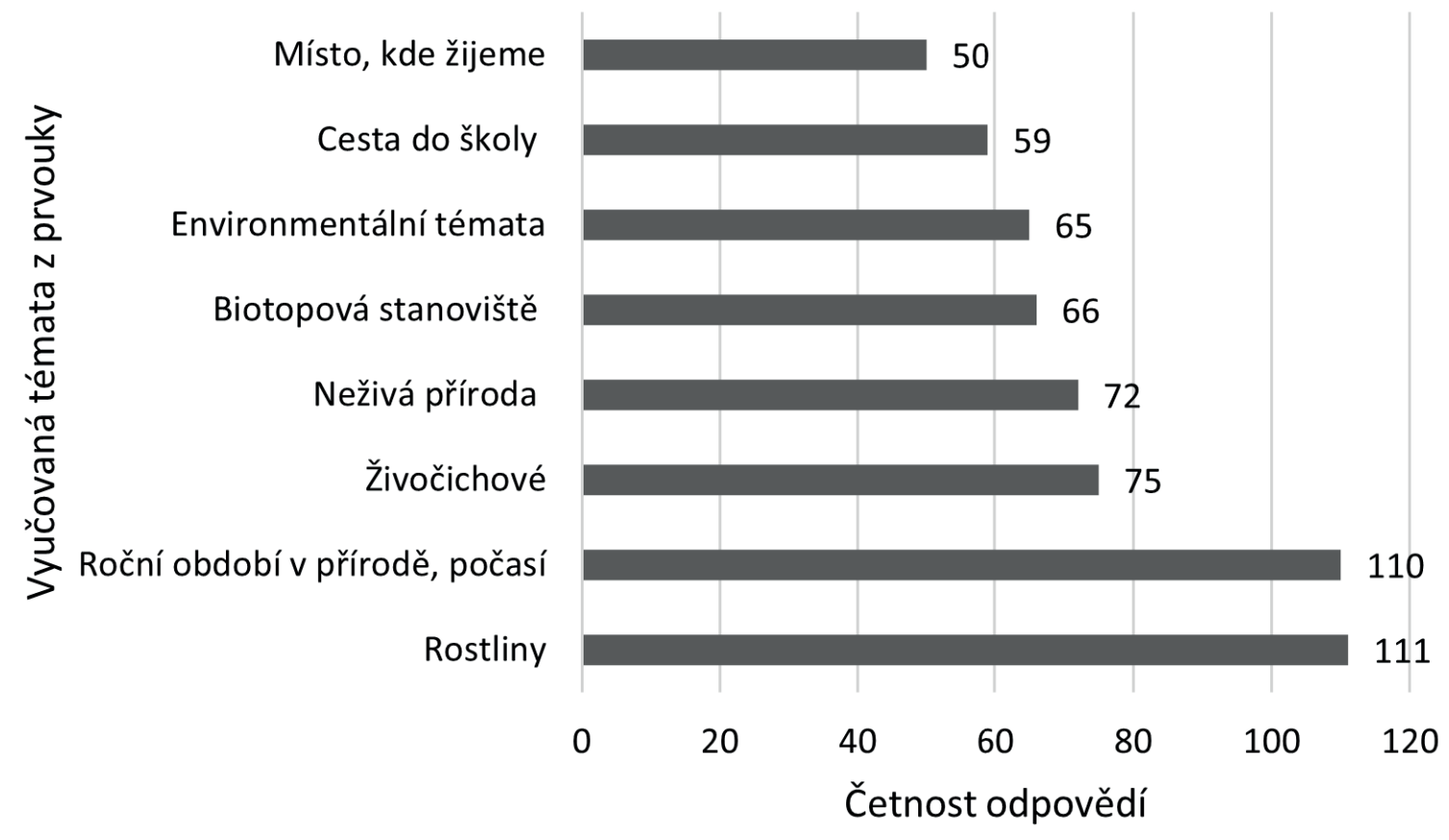


V přírodovědě jsou naopak nejčastěji zmiňovány biotopová stanoviště (les, louka, pole, zahrada a vodní biotop) a rostlinná říše, následuje učivo z živočišné říše (viz Obrázek 2). Nejméně zastoupené je téma neživá př́roda.

\section{Obrázek 2}

Vyučovaná témata z prírodovědy $(n=120)$

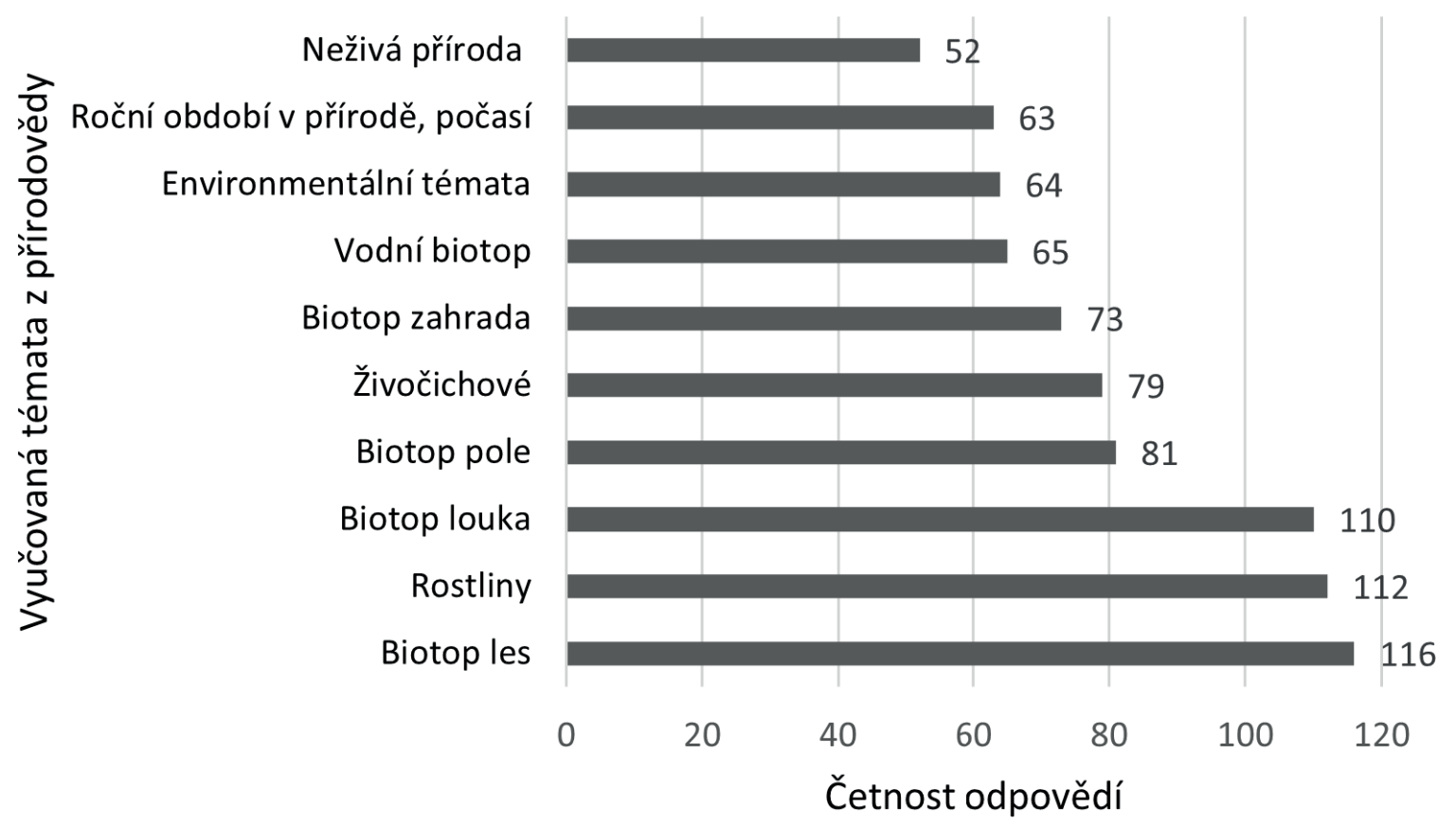

Výukovými metodami, které nejčastěji z nabídnutého výčtu respondenti používají, jsou pozorování (92\%), dále didaktické hry (73 \%) a projekty (34\%). Pokusy a badatelská metoda mají shodně četnost $28 \%$. Učitelé navíc ještě uváděli do kolonky jiný výběr například produkční metody ( $9 \%$ ) a pracovní činnosti (13\%). Zde pravděpodobně došlo k propojení př́rodovědných předmětů s jinými praktickými předměty (např pěstitelské práce - péče o rostliny na školní zahradě).

Pro zjednodušení vyhodnocení dotazníkového šetření byly výukové formy respondenty vybírány $\mathrm{z}$ výčtu možných odpovědí. $\mathrm{K}$ výběru byly zařazeny formy podle charakteru výukového prostředí. Mezi nejčastěji uváděné výukové formy patří krátkodobé vycházky (93\% respondentů) a exkurze po okolí školy (83\% respondentů), následuje přírodovědná hodina na školní zahradě (37 \% respondentů). Jako jiné byly nejčastěji respondenty uváděny jednodenní badatelské expedice (uvedlo $24 \%$ respondentů). Mnohdy patrně 
došlo k nepochopení významu termínu výukové formy. V dotazování nebyly cíleně uvedeny z vybíraných možností školní výlety, školy v přírodě, adaptační/seznamovací pobyty ani návštěvy muzeí apod. Výukové formy ale často bývají propojené i třeba s částečnou výukou ve třídě (Svobodová et al., 2019).

Pozitiva výuky ve venkovním prostředí z pohledu učitelů jsou uvedena v obrázku 3. Mezi nejčastěji uváděné př́nosy této výuky patří lepší názornost. Dále zmiňovali respondenti výuku na čerstvém vzduchu a následně pak bezprostřední manipulaci žáků s rostlinami, živočichy a dalšími přírodninami. Právě manipulaci s př́rodninami považuje za důležitou Podroužek (2005). Aplikace učení venku tak může být efektivní při rozvoji dovedností v přírodovědných předmětech (Wahyuni et al., 2017). Waite (2011) potvrdila ve svém výzkumu u dětí do 11 let věku v Anglii při výuce ve venkovním př́rodním prostředí pozitiva zjištěná i v této studii - např. zábavné učení, žáky více baví, vše vidí „naživo“ a mohou zapojit bohaté senzorické vnímání.

\section{Obrázek 3}

Pozitiva výuky ve venkovním prostředí pohledem učitelů $(n=120)$

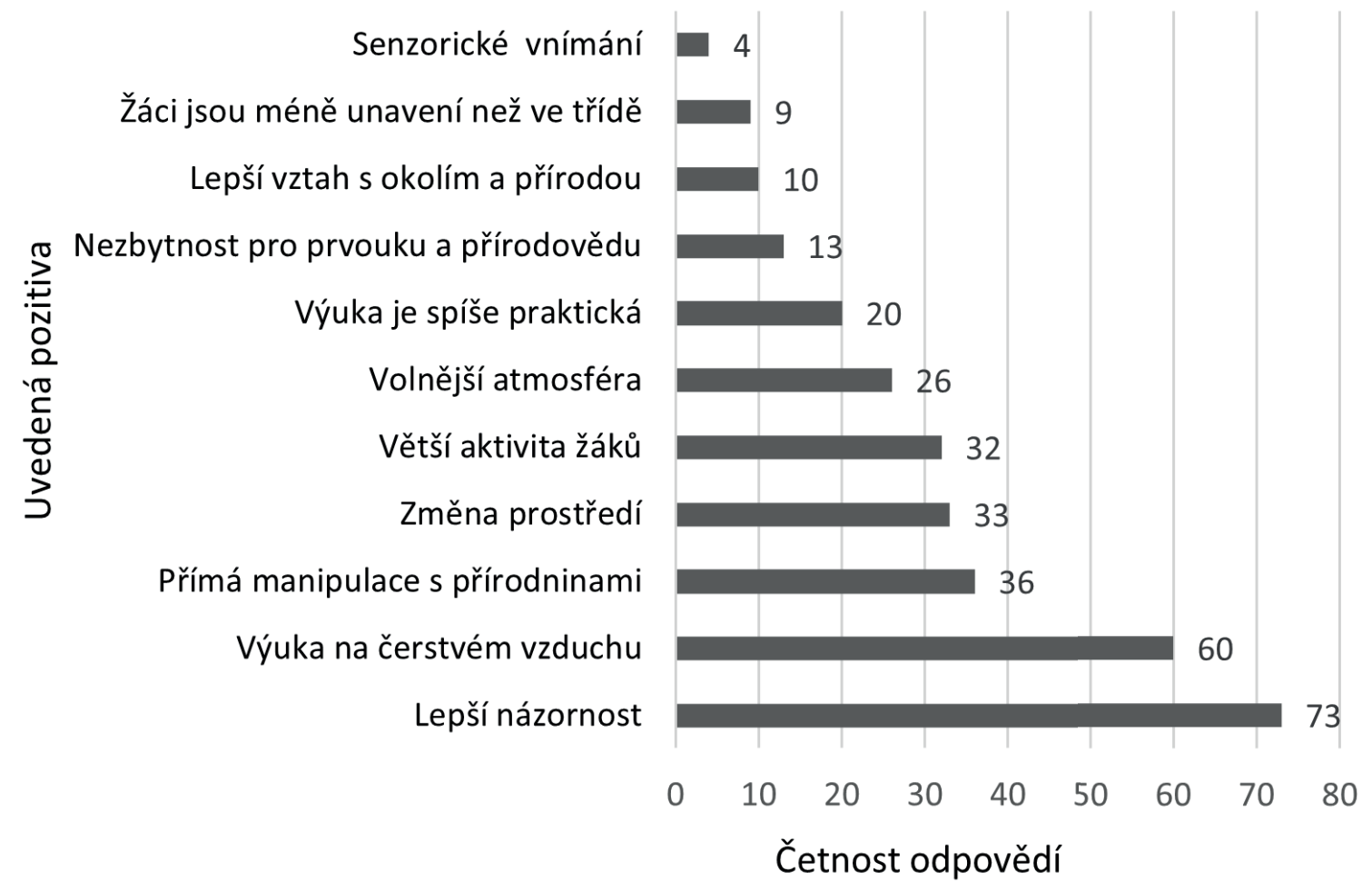

Většina učitelů (97 \%) hodnotí přístup žáků k této výuce pozitivně. V poznámkách na konci dotazníku ještě k této tematice respondenti mnohdy píší, 
že žáci 1 . stupně mají výuku venku rádi a s oblibou chodí do přírody, což mohou objektivně porovnat např. se zkušenostmi se žáky 2. stupně (kde je mnohdy těžší je pro výuku venku motivovat a zaujmout).

Další z otázek v dotazníku byla zaměřena na negativa výuky ve venkovním prostředí (obrázek 4). Někteří pedagogové považují za hlavní negativum závislost na počasí (25\%). Zbytek uvádí jako hlavní negativa zvýšené riziko úrazu (8\%). Dále je uvedena časová náročnost (10\%) a náročnost na př́ipravu (5\%). Dokonce v několika případech bylo navíc uvedeno i nevhodné oblečení žáků, které mnohdy zhoršuje výuku, protože se jim pak musí celá tř́ída přizpůsobit, a výuka ve venkovním prostředí tak musí být poupravena. Tyto výsledky se shodují se zjištěními Svobodové a kol. (2019), která jako bariéry ve výuce na 1. stupni také uvádí zajištění bezpečnosti žáků a počasí i neochotu financování ze strany rodičů a snížení celkové kondice žáků, a tudíž jejich neochotu vyrazit do terénu.

\section{Obrázek 4}

Uvedená negativa výuky ve venkovním prostředí pohledem učitelů ( $n=120)$

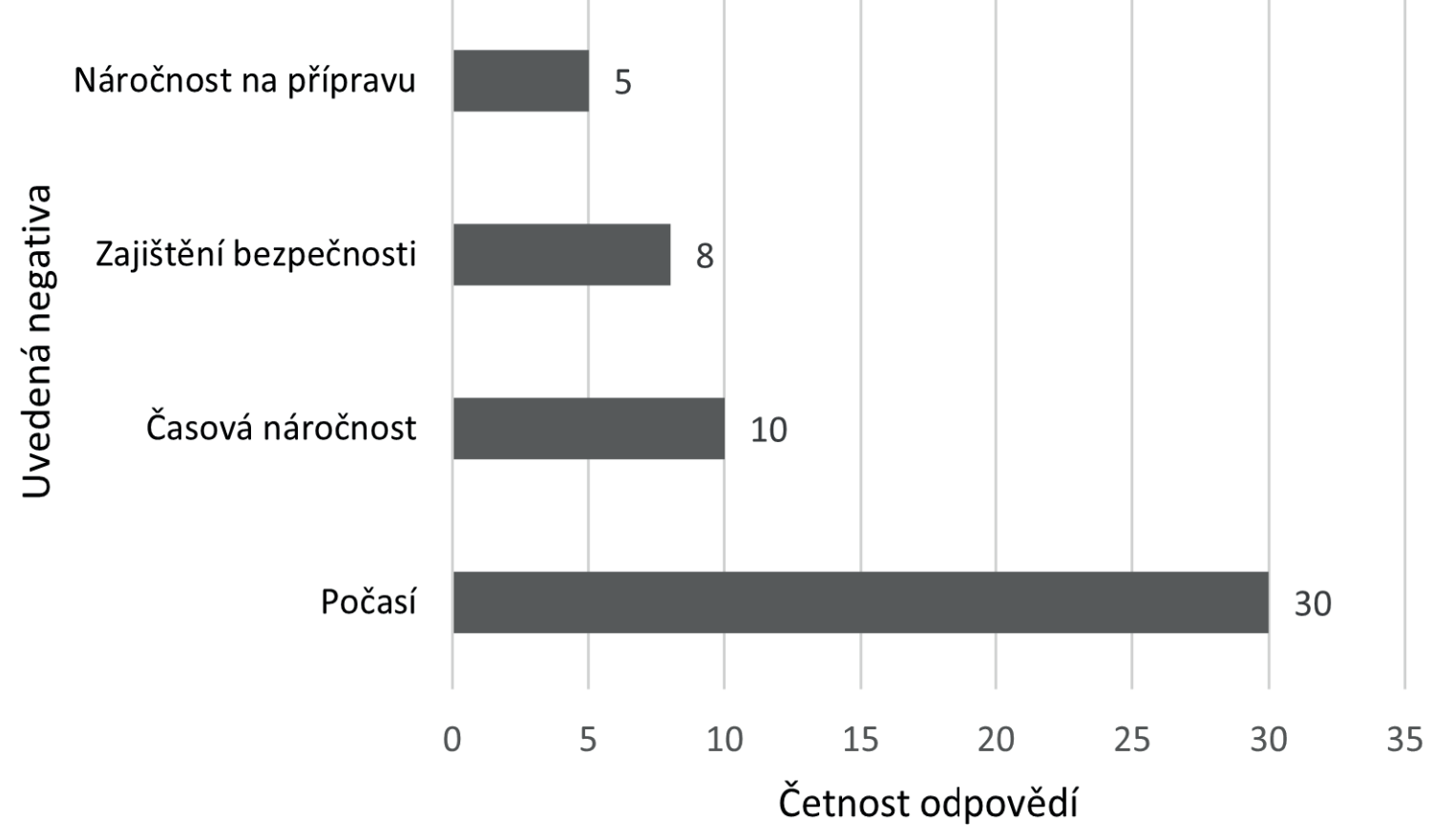

Materiály k výuce venku, které učitelé využívají nejvíce, jsou internetové zdroje (převážně české) - uvedeno 80 \% respondentů, dále vlastní zdroje (74 \% respondentů) a materiály jiných organizací, např. ekocenter (63\% 
respondentů). Nejméně využívané jsou pak školní učebnice a pracovní sešity (uvedlo $25 \%$ respondentů). Nabízí se tak možnost inovace školních učebnic a pracovních sešitů s cílem výuku ve venkovním prostředí do nich oficiálně více začlenit.

\subsection{Vyhodnocení ř́zených rozhovorů s učiteli}

Zajímavá zjištění poskytly řízené rozhovory s učiteli, při kterých učitelé převážně pozitivně hodnotili př́nosy výuky venku. Upozorňovali ale také na některá úskalí této specifické výuky. Při začátku rozhovoru bylo nutné si vzájemně upřesnit pojem výuka ve venkovním prostředí a její formy, které byl předmětem výzkumu (nebyly zahrnuty školní výlety, školy v př́rodě, adaptační/seznamovací pobyty ani návštěvy muzeí, výstav aj.).

V této kvalitativní studii nejsou uvedeny podrobně všechny řízené rozhovory, jen nejdůležitější výsledky a postřehy z nich. Celkem 20 respondentů z cílové skupiny souhlasilo s řízenými rozhovory. Řízené rozhovory obsahovaly celkem pět doplňujících otázek. U první otázky většina (18 respondentů z 20 dotazovaných) uvedla, že u žáků vnímá spíše pozitivní př́istup k výuce ve venkovním prostředí. Nikdo při rozhovoru neuvedl negativní prrístup ze strany žáků.

U postojů rodičů byly výsledky rozhovorů podobné. Většinou převládal dle učitelů kladný přístup rodičů k výuce ve venkovním prostředí; jen sporadicky učitelé uváděli neutrální přístup, zbytek učitelů to nemohl objektivně zhodnotit. Zde je uveden prŕklad části jednoho rozhovoru:

Rodiče nevnímají rozdíl mezi výukou ve třídě a výukou ve venkovním prostředí. Ale zřejmě je to tím, že máme kolem školy přírodu (i kolem naší obce) a často do ní chodíme se učit, tak rodiče to berou jako samozřejmost. (učitelka, 12 let praxe, vesnická škola v Jihočeském kraji)

Velmi zajímavé odpovědi poskytla třetí otázka: Máte nějaké zajímavé postřehy z výuky ve venkovním prostředí?

U této otázky učitelé uváděli, že občas mají problémy s koncentrací žáků na samotné učivo, nebot' v př́rodě/venku je mnoho rušivých vlivů. Naproti tomu však poukazovali na obrovské nadšení, které mají žáci, když se jdou tzv. učit ven. Někteří si stěžovali, že jim chybí prostředí v blízkosti školy, kam by chodili častěji, nebot' mají venkovní prostředí pro výuku daleko od školy. Některým dotazovaným chyběly i školní zahrady, kam by rádi směřovali 
„venkovní“ výuku. Většina dotazovaných však uvádí jako bonus výuky ve venkovním prostředí ještě skvělou atmosféru během této výuky. O’Brian a kol. (2011) svým výzkumem potvrzují, že vzdělávací aktivity v př́rodním prostředí přispívají k celkové pohodě žáků. Opět jsou uvedeny zajímavé části dvou rozhovorů:

Výuku ve venkovním prostředí jsem si velmi oblíbila, u žáků se tak zvyšuje prožitek, jsou samostatnější, i efektivita výuky je lepší. (učitelka, 5 let praxe, město $v$ Jihomoravském kraji)

Výuka ve venkovním prostředí v př́rodě mě a žáky nesmírně baví, musím být ale flexibilní a připravená na změnu tématu, protože najednou děláme místo herbáře atlas hmyzu. (učitelka, 15 let praxe, vesnická škola v Pardubickém kraji)

Rozhovor pokračoval otázkou, zda s sebou nese venkovní výuka z pohledu učitelů nějaké ohrožení zdraví žáků či bezpečnostní rizika (zda mají nějakou zkušenost s úrazy či poraněním). Jen při dvou rozhovorech bylo uvedeno ano - jednou ,jen odřená kolena“, v druhém případě zlomená noha. Ostatní učitelé neuvedli žádné další úrazy či poranění. Shodují se však na větší rizikovosti výuky ve venkovním prostředí a důležitosti hlídání dodržování bezpečnostních pravidel během této specifické výuky. Právě obavy o bezpečnost žáků jsou mnohdy jedním z limitujících faktorů výuky ve venkovním prostředí (Remington \& Legge, 2016; Svobodová et al., 2019).

Na otázku týkající se limitů a nevýhod výuky ve venkovním prostředí polovina z dotazovaných respondentů uváděla jako limit počasí, které samozřejmě nemohou ovlivnit a musí mnohdy výuku odložit nebo formálně upravit. Bariéru počasí uvádí ve svém výzkumu také Svobodová a kol. (2019). Byla uváděna i nesoustředěnost dětí, na což respondenti poukazovali již u třetí otázky v souvislosti se zhoršenou koncentrací žáků. Dva rozhovory upozorňovaly na velmi náročnou přípravu na výuku venku, jak materiální, tak zejména časovou, pro učitele, který musí např. projít celou trasu vycházky či exkurze předem. Zajímavý byl i následující postřeh: „Žáci to mnohdy neberou vůbec jako výuku..."

V některých případech byl uváděn i časový limit. Vyučující dodržují časové rozpětí či spojují hodiny. Výuka ve venkovním prostředí je tedy mnohdy realizována na úkor jiných předmětů. Pouze při jediném rozhovoru nebyla uvedena žádná úskalí výuky ve venkovním prostředí. Svobodová a kol. (2019) uvádí ve svém výzkumu jako klíčová omezení napřr. neochotu financování 
terénní výuky ze strany některých rodičůu, zajištění bezpečnosti žáků, počasí, případně neochota žáků vyrazit do terénu spojenou s vyrušováním i snižující se tělesnou kondici žáků, časovou náročnost a náročnost na přípravu.

Všech 20 dotazovaných se shoduje na problému s hodnocením žáků při výuce ve venkovním prostředí, s hodnocením žáků si v této oblasti neví rady, např::

Vůbec nevím, jak žáky během výuky v terénu hodnotit (známkovat), aby to bylo objektivní a spravedlivé. Formativní hodnocení si ještě dokážu představit, ale sumativní hodnocení zde asi nefunguje. (učitelka, 8 let praxe, město v Jihočeském kraji)

Rozhovory s učiteli poskytly poměrně cenné podněty k zamyšlení. Byla by potřeba určitě ještě další rozsáhlejší studie k problematice jednotlivých postřehů a problémů výuky ve venkovním prostředí vyplývající z těchto rozhovorů.

\section{Závěr}

Představená studie popisuje aktuální stav výuky přírodovědy a prvouky ve venkovním prostředí. Studie prokázala, že, až na ojedinělé výjimky, většina učitelů v našem výzkumném vzorku výuku ve venkovním prostředí na 1. stupni základní školy v rámci předmětů vzdělávací oblasti Člověk a jeho svět využívá. Odpověd' na hlavní výzkumnou otázku je v tomto případě kladná, dle zjištěných informací je výuka ve venkovním prostředí učiteli realizována. Výuka ve venkovním prostředí má celou řadu pozitiv potvrzených nejen mezinárodními výzkumy (uvedenými v úvodu této studie), ale i samotnými učiteli v této studii. Do zjištěných př́nosů této výuky dle názoru učitelů patři lepší názornost probraného učiva, výuka probíhající na čerstvém vzduchu, bezprostřední manipulace žáků s přírodninami, změna prostředí výuky a také směřování k praktické výuce.

Mezi limity tohoto výzkumu však můžeme zmínit omezený soubor respondentů (není zachycena celá edukační realita v rámci České republiky). Dotazníkový výzkum s sebou ovšem vždy nese úskalí v podobě zkreslení ze strany respondentů - uvedené odpovědi totiž mohou být lepší, než jaká je skutečnost. Rovněž autorský dotazník by bylo vhodné při dalších výzkumech upravit z hlediska odborné terminologie u výběru metod a forem výuky. 
Bohužel z námi realizovaného dotazníkového šetření nelze nějak blíže analyzovat cíle, rozsah a obsah učiva.

Z této studie ale vyplývá řada otázek, a může tak být východiskem pro odbornou diskuzi, jak konkrétně zakotvit výuku ve venkovním prostředí do vzdělávacích cílů. Tato práce poukazuje na některé problémy výuky ve venkovním prostředí, poukazuje na nedostatek oficiálních „školních“ materiálů pro učitele k této specifické výuce ve venkovním prostředí. Další otázkou pro následné studie mohou být i metodické postupy, jak během této výuky žáky hodnotit.

Zjištěné výsledky monitorují aktuální stav a realizaci výuky ve venkovním prostředí na poměrně širokém souboru respondentů, a proto mohou být pilotní studií popisující aktuální situaci venkovní výuky přírodovědných předmětů v současné školní praxi na 1 . stupni základní školy.

\section{Literatura}

Asah, S. T., Bengtsson, D. N., \& Westphal, L. M. (2012). The influence of childhood: Operational pathways to adulthood participation in nature-based activities. Environment and Behavior, 44(4), 545-569.

Bento, G., \& Dias, G. (2017). The importance of outdoor play for young children's health. Porto Biomedical Journal, 5(5), 157-160. http://dx.doi.org./10.1016.j.pbj.2017.03.003

Bentsen, P., Mygind l., Elsborg, P., Nielsen G., \& Mygind E. (2021). Education outside the classroom as upstream school health promotion: 'Adding-in' physical activity into children's everyday life and settings. Scandinavian Journal of Public Health, February 2021. https://journals. sagepub.com/doi/10.1177/1403494821993715

Berg, S., Bradford, B., Barrett, J., Robinson, D. B., Camara, F., \& Perry, T. (2020). Meaning-making of student experiences during outdoor exploration time. Journal of Adventure Education and Outdoor Learning, 21(2), 172-183. https://doi.org/10.1080/14729679.2020.1769694

Blair, D. (2009). The child in the garden: an evaluative review of the benefits of school gardening. Journal of Environmental Education, 40(2), 15-38.

Brtnová Čepičková, I. (2013). Didaktika přírodovědného základu. Univerzita J. E. Purkyně Ústí nad Labem.

Burešová, L., Endrštová, V., Glovňová, M., Krulichová, M., A., Kulich, J., \& Kulichová, H. (2019). Prostor pro rozvoj odpovědného jednání k př́rodě a lidem $v$ RVP a vybraných ŠVP. Výsledky srovnávací analýz, projekt CIVIS, Lipka o.p.s. https://www.lipka.cz/soubory/analyza-svp_ rvp_final--f11960.pdf

Činčera, J., \& Holec, J. (2016). Outdoor education in formal education. Envigogika, 11(2).

Činčera, J., Králíček, I., Bílek, M., Loudová, I., Machková, V., Musílek, M., Štindl, P., Švarcová, E., \& Vízek, L. (2019). Výuka ve venkovním prostředí. Metodický text pro studenty učitelství. Gaudeamus.

Daniš, P. (2016). Děti venku v př́rodě: ohrožený druh? Ministerstvo životního prostředí. 
Daniš, P. (2018). Tajemství školy za školou: Proč učení venku v př́rodě zlepšuje vzdělávací výsledky, motivaci a chování žákủ. Ministerstvo životního prostředí.

Hajerová Müllerová, L., \& Slavík, J. (2020). Modelování kurikula. Západočeská univerzita.

Hejnová, E. (2011). Integrovaná výuka přírodovědných předmětů na základních školách v českých zemích - minulost a současnost. Scientia in Educatione, 2(2), 77-90.

Held, L. (2011). Konfrontácia koncepcií prírodovedného vzdelavania v Európe. Scientia in Educatione, 2(1), 69-79.

Hendl, J. (2016). Kvalitativní výzkum: základní metody a aplikace. Portál.

Hofmann, E. (2003). Integrované terénní vyučování. Paido.

Hofmann, E., Trávníček, M., \& Soják, P. (2011). Integrovaná terénní výuka jako systém. In T. Janík, P. Knecht, \& S. Šebestová (Eds.), Smíšený design v pedagogickém výzkumu: Sborník př́spěvků z 19. výroční konference České asociace pedagogického výzkumu (s. 310-315). Masarykova univerzita.

Chmelová, Š. (2010). Pěstitelství na základní škole I. Didaktika výuky. Jihočeská univerzita v Českých Budějovicích.

Chmelová, Š., Ryplová, R., Vácha, Z., Vaněčková, O., \& Procházka, M. (2019). School gardens and their potential for environmental education. Envigogika, 14(1). https://www.envigogika. cuni.cz/index.php/Envigogika/article/view/580/812

Jančař́ková, K. (2010). Pedagogika pod širým nebem. Sedmá generace, 22. únor 2010. https:// sedmagenerace.cz/pedagogika-pod-sirym-nebem/

Jančař́ková, K., \& Kapuciánová, M. (2012). Environmental education in nursery schools - finding the optimal form. Envigogika, 7(1). http://www.envigogika.cuni.cz/index.php/Envigogika/ article/view/71/75

Louv, R. (2008). Last child in the woods. Saving our children from nature-deficit disorder. Algonquin Books of Chapel Hill.

Marchant, E., Todd, C., Cooksey R., Dredge, S., Jones, H., Reynolds, D., Stratton, G., Dwyer, R., Lyons, R., \& Brophy, S. (2019). Curriculum-based outdoor learning for children aged 9-11: A qualitative analysis of pupils' and teachers' views. PLOS ONE, 14(5). https://doi. org/10.1371/journal.pone.0212242

McSweeney, K., \& WinklerPrins, A. (2020). Introduction to the special issue: Fieldwork in the the 21st century. Geographical Review, 110(1-2), 1-7. https://doi.org/10.1080/0016742 8.2019.1689361

MŠMT. (2020). Metodické doporučení pro distanční výuku. https://www.edu.cz/wp-content/ uploads/2020/09/metodika_DZV_23_09_final.pdf

MŠMT. (2021). Opatření ministra školství, mládeže a tělovýchovy, kterým se mění Rámcový vzdělávací program pro základní vzdělávání. https://www.msmt.cz/file/54860/

Nadace Proměny Karla Komárka. (2016). České děti venku: Reprezentativní výzkum, kde a jak tráví děti svůj čas. http://www.nadace-promeny.cz/cz/vyzkum.html

Oost, K., De Vries, B., \& Van der Schee, J. A. (2011). Enquiry-driven fieldwork as a rich and powerful teaching strategy - school practices in secondary geography education in the Netherlands. International Research in Geographical and Environmental Education, 20(4), 309-325.

Podroužek, L. (2003). Didaktika prvouky a př́rodovědy pro primární školu. Aleš Čeněk. 
Podroužek, L. (2005). Přírodovědné vzdělání a získávání didaktických kompetencí v didaktice přírodovědy u studentů učitelství 1 . stupně základní školy v souvislosti s RVP ZV. In R. Jandová (Ed.), Příprava učitelů a aktuální proměny v základním vzdělávání (s. 162-164). Jihočeská univerzita v Českých Budějovicích.

Punch, K. (2008). Úspěšný návrh výzkumu. Portál.

Rámcový vzdělávací program pro základní vzdělávání (2017). MŠMT. https://www.msmt.cz/ file/43792/

Remington, T., \& Legge, M. (2017). Outdoor education in rural primary schools in New Zealand: A narrative inquiry. Journal of Adventure Education and Outdoor Learning, 17(1), 55-66.

Ryplová, R., Chmelová, Š., \& Vácha, Z. (2019). Školní zahrady ve výuce. Epika.

Suttie, J. (2018). The surprising benefits of teaching a class outside. A new study finds that a class in nature helps kids be more attentive and focused once they return indoors. Greater Good Magazine Science-Based Insights for a Meaningful Life, 14. 5. 2018. https://greatergood. berkeley.edu/article/item/the_surprising_benefits_of_teaching_a_class_outside

Svobodová, H., Durna, R., Mísařová, D., \& Hofmann, E. (2019). Komparace formálního ukotvení terénní výuky ve školních vzdělávacích programech a její pojetí v modelových základních školách. Orbis Scholae, 13(2), 95-116.

Šimik, O., Švrčková, M., Sztablová, D., Poledníková, J., Holubová, B., Pisklák, B., Durčáková, H., Hyplová, J., Babůrková, D., Klimtová, H., Karaffa, J., \& Cisovská, H. (2010). Metodika výuky jednotlivých předmětů na 1. stupni základních škol z pohledu pedagogické praxe - námèty pro začínajícího učitele. Ostravská univerzita. https://projekty.osu.cz/synergie/dok/ opory/simik-metodika-vyuky-jednotlivych-predmetu-na-1-stupni-zs.pdf

Šimik, O. (2015). Člověk a jeho svět - úvod do studia. Ostravská univerzita. https://www.simiko. cz/wp-content/uploads/2016/09/\%C4\%8Clov\%C4\%9Bk-a-jeho-sv\%C4\%9Bt-do-tisku. pdf

Vácha, Z. (2015). Didaktické využití školních zahrad v České republice na primárním stupni základních škol. Scientia in Educatione, 6(1), 80-90.

Veřmiřovský, J., \& Oujezdský, A. (2014). Konstruktivistický přístup k výuce př́rodovědných a technických předmětů na základních školách. Edukacja-Technika-Informatyka, 5(1), 142-146. http://cejsh.icm.edu.pl/cejsh/element/bwmeta1.element.desklight-dcb21c757d07-4241-b0de-1b95ae255aa0

Wahyuni, S., Indrawati, I., Sudardi, S., \& Suana, W. (2017). Developing science process skills and problem solving abilities based on outdoor learning in junior high school. JPII, 6(1), 165-169. https://doi.org/10.15294/jpii.v6i1.6849

Waite, S. (2011). Teaching and learning outside the classroom: Personal value, alternative pedagogies and standards. Education 3-13, 39(1), 65-82. https:// doi:10.1080/03004270903206141

Wells, N. M. (2000). At home with nature effects of "greenness" on children's cognitive functioning. Environment and Behavior, 32(6), 775-795. https://doi:10.1177/00139160021972793

Williams, D., R., \& Brown, J. D. (2012). Learning gardens and sustainability education. Taylor\& Francis. 


\title{
Autor
}

Ing. Štěpánka Chmelová, Ph.D., Jihočeská univerzita v Českých Budějovicích, Pedagogická fakulta, Katedra biologie, Jeronýmova 10, 37115 České Budějovice, e-mail: chmel@pf.jcu.cz

\section{How teachers use education outside the classroom for instruction within the educational area Humans and their world}

\begin{abstract}
The main goal of this study was to find out how primary school teachers currently use education outside the classroom. Even though primary school teachers usually teach a whole range of subjects, the study's attention was focused only on primary science. In the Czech Republic, primary science is a part of the educational area Humans and their world. A total of 120 teachers teaching primary science at primary school (Grade 1-5) in the Czech Republic participated in this study. Data were collected using a non-standardized questionnaire designed by the author of the study, which contains a total of 18 questions. The study took place in 2019 and 2020 and thus recognizes the current state of this teaching in the education outside the classroom. It was found that $96.7 \%$ of respondents regularly use teaching in the outdoor environment. In addition, the study was supplemented by interviews with 20 teachers from practice, who were asked 5 questions on the topic of teaching in the education outside the classroom.
\end{abstract}

Keywords: Humans and their world, teaching in the education outside the classroom, questionnaires 


\section{Př́íloha Dotazník pro učitele 1. stupně ZŠ}

\section{Dotazník - Výuka prvouky a přírodovědy ve venkovním prostředí}

Pohlaví (zakroužkujte): žena/muž

Délka učitelské praxe:

Základní škola, na které učím, se nachází (zakroužkujte):

a) ve městě městská s počtem obyvatel nad 100 tis. obyvatel

b) ve městě městská s počtem obyvatel od 50 tis. do 100 tis. obyvatel

c) ve městě s počtem obyvatel městská pod 50 tis. obyvatel

d) na vesnici

Kraj:

Odpovězte na následující otázky (vypište, zakroužkujte):

1. Využíváte výuku ve venkovním prostředí v rámci prvouky a přírodovědy? ANO x NE pokud NE, již dále nevyplňujte a zdůvodněte, proč výuku venku nerealizujete

2. Škola, na které učím, má vlastní školní zahradu: ANO x NE

Pokud NE, pokračujte otázkou 6. Pokud ANO:

3. Na školní zahradě vyučuji prvouku a přírodovědu: ANO x NE

4. Na školní zahradě učím ještě tyto další předměty:

ANO (vyberte): x NE

a) výtvarná výchova

b) tělesná výchova

c) pracovní činnosti

d) cizí jazyk

e) český jazyk

f) matematika

g) jiné

5. Na školní zahradě neučím, protože 
6. Na výuku do venkovního prostředí chodím se žáky:
a) $1 x$ týdně
b) $1 \mathrm{x}$ za měsíc
c) 1x za 3 měsíce
d) 1 x za 6 měsíců
e) $1 \mathrm{x}$ ročně
f) jiné

7. Využívám především výuku v tomto venkovním prostředí:
a) v parku
b) na školní zahradě
c) prostředí hned u školy (trávník aj.)
d) vycházky do okolí (pole, lesy aj.)
e) jiné

8. Výuku ve venkovním prostředí nejčastěji učím:
a) 1 hodinu - $45 \mathrm{~min}$.
b) spojuji 2 a více vyučovacích hodin
c) v půldenním bloku
d) v bloku celý den
e) jiné

9. Př́́prava na jednu vyučovací hodinu výuky venku mi zabere zpravidla:
a) 30 minut
b) 1 hodina
c) 2 hodiny
d) více jak 3 hodiny
e) jiné 
10. S materiálním vybavením školy pro výuku ve venkovním prostředí jsem spokojen(a):

ANO x NE

Pokud NE, uved'te proč

11. Ve venkovním prostředí učím tato témata z prvouky:
a) cesta do školy a místo, kde žijeme
b) biotopová stanoviště
c) rostliny
d) živočichové
e) neživá př́ŕroda - půda, horniny a nerosty
f) environmentální témata
g) roční období v přírodě, počasí
h) jiné

12. Ve venkovním prostředí učím tyto témata z přírodovědy:
a) biotop pole
b) biotop louka
c) biotop les
d) vodní biotop
e) biotop zahrada
f) environmentální témata
g) neživá př́ŕroda - půda, horniny a nerosty
h) roční období v přírodě, počasí
i) rostliny
j) živočichové
k) jiné 
13. Při výuce ve venkovním prostředí zařazuji nejčastěji tyto výukové metody:
a) pozorování
b) pokusy
c) projektová metoda
d) badatelská metoda
e) didaktické hry
f) jiné

14. Při výuce ve venkovním prostředí zařazuji nejčastěji tyto výukové formy:
a) exkurze
b) vycházky
c) hodina na školní zahradě
d) jiné

15. Výhody/přínosy výuky ve venkovním prostředí vnímám tyto:

16. Vypište, jaké naopak vnímáte nevýhody/limity výuky ve venkovním prostředí vnímám tyto:

17. Jak podle Vás výuku ve venkovním prostředí vnímají žáci?
a) pozitivně
b) negativně
c) neutrálně

18. Materiály pro výuku ve venkovním prostředí čerpám převážně z těchto zdrojů:
a) vlastní navržené materiály
b) školní učebnice a pracovní sešity
c) internetové zdroje
d) materiály jiných organizací, např. ekocenter
e) jiné 